\title{
EFFECT OF REPLACEMENT DIETARY FISH MEAL BY RICE PROTEIN CONCENTRATE ON PERFORMANCE, BODY COMPOSITION AND INTESTINAL HISTOLOGY IN NILE TILAPIA (OREOCHROMIS NILOTICUS)
}

\author{
Ahmed F. K. Assi ; Asmaa T.Y. Kishawy* ; Mohamed E. Badawi \\ and EL-Sayed I. Hassanein \\ Department of Nutrition and Clinical Nutrition, Faculty of Veterinary Medicine, \\ Zagazig University, Zagazig 44519, El-Sharkia, Egypt. \\ *Correspondence | Asmaa TY Kishawy; Email: No.dispair2000@gmail.com
}

Key Words: Oreochromis. niloticus, Rice protein concentrate, Growth, amino acid, intestinal histology

\section{ABSTRACT}

The present study was designed to study the effect of the partial or complete substitution of fish meal by rice protein concentrate (RPC) in the diets of Nile tilapia (O. niloticus) and their effect on the growth performance parameters, body composition and intestinal histology. A total of $320 \mathrm{O}$. niloticus with an average body weight of $40.50 \pm 0.250 \mathrm{~g}$ were used. The fish were randomly divided into four equal replicate groups (each replicate contains 20 fish). A basal control diet was formulated with zero replacement of fish meal $(\mathrm{G} 1)$ and the other experimental groups $(\mathrm{G} 2, \mathrm{G} 3$ and $\mathrm{G} 4)$ received a basal diet contained fish meal substituted with $25 \%, 50 \%$, and $100 \%$ of RPC, respectively. The fish were fed isonitrogenous and isocaloric diets; three times daily at a rate of $3 \%$ of the body weight for 90 days. Body weight was not affected by substituting fish meal by $100 \%$ of RPC compared to control, while at this level of replacement, feed intakes, and feed conversion ratios were higher than in the control group. Protein efficiency ratio and the protein retention efficiency were reduced by replacing fish meal with RPC at the level of $25 \%, 50 \%$, and $100 \%$ than control group. The results showed that substitution of $50 \%$ and $100 \%$ of fish meal with RPC had recorded significant lower protein, calcium and phosphorus and higher fat content than control group. All experimental groups fed RPC -based diet had a significant lowered cysteine, methionine, lysine, threonine and serine than the control group. On the other hand, the experimental groups fed RPC -based diet showed a significant higher intestinal villus height, crypt depth and muscle thickness.

\section{INTRODUCTION}

In Egypt, there is an attention for the aquaculture industry to find high nutritional and more economical protein sources to replace the traditional protein ingredients such fish meal (FM). (Katya et al., 2014). 
However, the very nice nutritive value of FM, its price was very expensive as well as the unstable production and little availability in the market. Consequently, to allow the sustainability of the aquaculture industry, it is of great significance to explore other protein alternatives to fish meal in the aqua diets. In this approach, vegetable protein meals are very good candidates due to their rich abundance and relatively low cost (Olsen and Hasan, 2012).

Rice protein concentrate (RPC) has been reported to be an alternative protein raw materials of fish meal due to its high content of protein and lipid profile (Cai et al., 2018). Unfortunately, lysine was the first limiting indispensable amino acid in RPC, as limits its utilization in the aqua diets (Gatlin et al., 2007). Accordingly, synthetic lysine could be supplemented for balancing the amino acid profile of the aqua diet to enhance the usage of RPC. Fish meals could be substituted by rice protein concentrate tell $50 \%$ without deteriorative effect on the growth performance parameters, hematological parameters, and the nutrient digestibility up to $20 \%$ in the rainbow trout (Palmegiano et al., 2006). Also RPC could replace fish meal tell $64 \%$ in the blackspot seabream (Dapra et al., 2009) and up to $90 \%$ in the gilthead seabream (SanchezLozano et al., 2009). In shrimp RPC reached up to $50 \%$ fish meal replacement without adverse effect on performance (Oujifard et al., 2012), up to $25 \%$ in the European sea bass juveniles (Guroy et al., 2013), up to $18 \%$ with microcapsule lysine addition in the Chinese softshelled turtle (Sun et al., 2018) and up to $100 \%$ with lysine addition (Cai et al., 2018).

The aim of this study was to evaluate the effect of the partial or total replacement dietary fish meal protein with rice protein concentrate on O. niloticus's growth performance parameters, body and amino acids composition and intestinal histology.

\section{Ethical Statement}

\section{MATERIALS AND METHODS}

The ethics of the experimental protocol were performed following the recommendations of the local experimental fish care committee of the Faculty of Veterinary Medicine, Zagazig University (ZU-IACUC) with Approval No. ZU-IACUC/2/F/116/2020)

Experimental Fish

A total number of 320 healthy live $O$. niloticus with an average body weight of $40.50 \pm 0.250 \mathrm{~g}$ were obtained from a private fish farm, Abbassa village, Abu-Hammad district, Sharkia Governorate, Egypt. Fish 
were stocked in a clean concrete ponds ( $3 \times 1 \times 1$ meter) and filled with de-chlorinated freshwater and aerator. The water temperature $\left({ }^{\circ} \mathrm{C}\right)$, the dissolved oxygen ( $\mathrm{DO}, \mathrm{mg} / \mathrm{L}), \mathrm{pH}$, ammonium ( $\mathrm{NH} 4, \mathrm{mg} / \mathrm{l})$, and nitrite (NO2, mg/L) were measured by using bag of water aquarium analysis and found to be $27 \pm 2^{\circ} \mathrm{C}, 5.4 \mathrm{mg} / \mathrm{l}, 7.2,0.20 \mathrm{mg} / \mathrm{l}$ and $0.02 \mathrm{mg} / \mathrm{l}$, respectively. Fish were divided into four equal replicate groups (each replicate contain 20 fish). The fish were adapted to the experimental conditions for two weeks before starting of the experiment.

\section{Fish diets and feeding}

The control group received a basal diet without rice protein concentrate (G1) and other experimental groups (G2-4) received a basal diet contained fish meal substituted with $25 \%, 50 \%$, and $100 \%$ RPC, respectively. All fish were fed their respective diet at a level of $3 \%$ of the body weight three times daily for 90 days. Feedstuffs used in diets formulation were analyzed for moisture, dry matter (DM), crude protein $(\mathrm{CP})$, Ether extract (EE), and crude fiber (CF) according to the standard procedures of the International guidelines (Feldsine et al., 2002). The results of the chemical analysis, as well as, the nutritive value in the diets were listed in Table 1. Isocaloric and isonitrogenous diets were prepared at Fish Research Center, Faculty of Veterinary medicine, Zagazig University, Egypt. It contained $(3007 \mathrm{kcal} / \mathrm{kg}$ metabolizable energy and $32 \%$ crude protein) in the form of dry pellets and were formulated to match the nutrient requirements of $O$. niloticus set by National Research Council (1993) as shown in Table 1.

\section{Growth performance traits}

The all-experimental fish (80) of each group were weighed at the start and the end of the experiment. The average body weight was calculated by dividing the total weight of fish by the number of the fish in each group. Body weight gains, feed conversion ratios (Siddiqui et al., 1988), body gains percent (Jauncay and Ross, 1982) and specific growth rates \% (Nathanailides et al., 2019) were detected. The following growth performance parameters indicators were calculated as a protein efficiency ratio (Stuart and Hung, 1989), and Protein retention efficiencies (Castell and Tiews, 1980). The mortalities were recorded and the relative survival percentage calculated by subtraction of the mortality from the total number of fish.

Chemical, amino acids analysis of whole-body composition: a-Chemical analysis of fish body

For calculation of the whole-body composition, 5 fish from each treatment group at the end of the experiment were minced then dried at $70^{\circ} \mathrm{C}$ for 72 hours in hot air oven and used for determination of moisture, crude protein, ether extract, and ash according to (AOAC, 2012). 
Table 1. Chemical composition of the experimental diets.

\begin{tabular}{|c|c|c|c|c|}
\hline \multirow[t]{3}{*}{ Ingredients } & \multicolumn{4}{|c|}{ Experimental diets } \\
\hline & \multirow[t]{2}{*}{ Control } & \multicolumn{3}{|c|}{ Rice protein concentrate } \\
\hline & & $25 \%$ & $\mathbf{5 0 \%}$ & $100 \%$ \\
\hline Fish meal, $66 \%$ & 20 & 15 & 10 & $\mathbf{0}$ \\
\hline $\begin{array}{l}\text { Rice protein } \\
\text { concentrate }\end{array}$ & $\mathbf{0}$ & 5 & 10 & 20 \\
\hline Soybean meal, $\mathbf{4 4 \%}$ & 20 & 20 & 20 & 20 \\
\hline DDGS, $28 \%$ & 10 & 10 & 10 & 10 \\
\hline Yellow corn & 15 & 15 & 15 & 15 \\
\hline Corn gluten, $\mathbf{6 2} \%$ & 4.55 & 5.20 & 6.25 & 8 \\
\hline Rice bran & 26.45 & 25.80 & 25.30 & 24.15 \\
\hline Vegetable oil & 3.50 & 3.50 & 2.85 & 2.20 \\
\hline L-Lysine HCL, 78 \% & - & - & - & - \\
\hline DL-Methionine, $98 \%$ & - & - & 0.10 & 0.15 \\
\hline Calcium carbonate & - & - & - & - \\
\hline $\begin{array}{l}\text { Vitamin mineral } \\
\text { premix* }\end{array}$ & 0.50 & 0.50 & 0.50 & 0.50 \\
\hline Total, \% & 100 & 100 & 100 & 100 \\
\hline \multicolumn{5}{|l|}{ Calculated composition } \\
\hline DM, \% & 86.47 & 86.48 & 86.20 & 85.79 \\
\hline CP, \% & 32.01 & 32.04 & 32.01 & 32.05 \\
\hline EE, \% & 11.47 & 11.11 & 10.93 & 10.51 \\
\hline $\mathrm{CF}, \%$ & 4.27 & 4.30 & 4.24 & 4.18 \\
\hline Ash, \% & 7.60 & 6.76 & 5.82 & 4.01 \\
\hline NFE, \% & 34.06 & 35.21 & 35.79 & 37.26 \\
\hline $\mathrm{Ca}, \%$ & 0.89 & 0.71 & 0.79 & 0.77 \\
\hline $\mathbf{P}, \%$ & 1.19 & 1.07 & 0.94 & 0.68 \\
\hline Lysine, \% & 1.85 & 1.69 & 1.63 & 1.60 \\
\hline Methionine, \% & 0.71 & 0.76 & 0.81 & 0.90 \\
\hline DE, Kcal/ kg** & 3007.46 & 3008.87 & 3006.77 & 3008.69 \\
\hline
\end{tabular}

* Vitamin and mineral mixture sourced from Trouw nutrition, Netherlands $(5 \mathrm{~kg} /$ diet) \{Vit. A 6000 I.U, D3 2.000 I.U, E $300 \mathrm{mg}, \mathrm{k3} 7.5 \mathrm{mg}$, C $500 \mathrm{mg}$. B $12 \mathrm{mg}$, $B^{2} 24 \mathrm{mg}, B_{6} 24 \mathrm{mg}, B_{12} 0.036 \mathrm{mg}$, Biotin $0.21 \mathrm{mg}$, Folic acid $4.5 \mathrm{mg}$, choline $1500 \mathrm{mg}$ inositol, $150 \mathrm{mg}$, pantothemic acid $72 \mathrm{mg}$, Nicotinic acid $90 \mathrm{mg}$, iron $3 \mathrm{mg}$, copper $5 \mathrm{mg}$, zinc $150 \mathrm{mg}$, Sodium selenite $0.2 \mathrm{mg}$ and, potassium iodide 2 mg\}.

** Digestible energy calculation based on values of protein $3.5 \mathrm{kcal} / \mathrm{gm}$, fat 8.1 $\mathrm{kcal} / \mathrm{gm}$, NFE $2.5 \mathrm{kcal} / \mathrm{gm}$ according to (Santiago et al., 1982).

b- Amino acids analysis of fish body by HPLC amino acids analyzer

Analysis of amino acids by HPLC amino acids analyzer

Before HPLC analysis of amino acids, the fish samples were subjected to a process of sample preparation. Samples of fish body were 
homogenized using an Ultra Turrax grind mixer (IKA, Staufen, Germany) at high speed $(11.93 \mathrm{~m} / \mathrm{s}$ for $1 \mathrm{~min})$. The amino acids analysis was done by the method described by (Garde-Cerdán et al. 2014). Free amino acids were analyzed by HPLC (Agilent, Palo Alto, USA). Each sample ( $5 \mathrm{ml}$ of supernatant) was mixed with $100 \mu \mathrm{l}$ of norvaline and 100 $\mu l$ of sarcosine (internal standards). The mixture was submitted to an automatic precolumn derivatisation with o-phthaldialdehyde (OPA Reagent, Agilent) and with 9-fluorenylmethylchloroformate (FMOC Reagent, Agilent). The injected amount from the derived sample was 10 $\mu \mathrm{l}$, and a constant temperature of $40^{\circ} \mathrm{C}$ was maintained. All separations were performed on a Hypersil ODS $(250 \times 4.0 \mathrm{~mm}$, I.D. $5 \mu \mathrm{m})$ column (Agilent). Two eluents were used as mobile phases: eluent A: $75 \mathrm{mM}$ sodium acetate $+0.018 \%$ triethylamine $(\mathrm{pH} 6.9)+0.3 \%$ tetrahydrofuran; eluent B: water, methanol, and acetonitrile (10:45:45, v/v/v). Detection was performed by fluorescence detector FLD, and DAD detector. Identification of compounds was performed by comparison of their retention times with those of pure reference standards. The pure reference compounds and internal standards were from Sigma-Aldrich (Madrid, Spain).

c- Calcium and phosphorus analysis

Atomic absorption measurements were made with a Perkin-Elmer 4000 Atomic Absorption Spectrophotometer. Flame photometry measurements were made with an Instrumentation Laboratory (IL) Model 343 Digital Flame Photometer. The method described by (Dipietro, et al., 1988). $2 \mathrm{ml}$ of hydrochloric and $3 \mathrm{ml}$ of nitric acids were used for each sample. Atomic absorption standard solutions $(1000 \mathrm{mg})$ were certified accurate within $1 \%$ by the manufacturer. The samples homogenate were mixed with $2 \mathrm{ml}$ hydrochloric and $3 \mathrm{ml}$ nitric acids incubated for $24 \mathrm{hr}$ then filtrated, the filtrate used for minerals measurement using the flame atomic absorption spectroscopy according to (Bayse, et al., 1981).

\section{Intestinal histological examination}

The intestine (from the middle part) was collected for histometric evaluation. The samples were immediately fixed in a paraformaldehyde solution, followed by slide processing that included washing, dehydration using different grades of alcohol, clearing by xylene, and embedding in paraffin wax. The wax blocks were sectioned into five-micron thick sections; the sections were stained with haematoxylin and eosin (H\&E) 
to prepare histological slides according to the method by (Roberts 2001). The villi length, crypt depth and muscle thickness were measured.

\section{RESULT AND DISCUSSION}

\section{Growth performance}

Effect of the replacement fish meal with RPC in O. niloticus diets on overall growth performance was shown in (Table 2). The final body weight of the control group had slight non-significant increase with the other three groups of RPC levels $25 \%, 50 \%$, and $100 \%$. In addition, final body weight gain and gain percentage of the control group significantly increased $(\mathrm{P} \leq 0.05)$ in group fed RPC $50 \%$ but no significant differences were observed among the control group and the other groups $(25 \%$ and $100 \%)$. Regarding to the total feed intake, the control group had marked decrease in total feed intake $(\mathrm{P} \leq 0.05)$ when compared with the group fed $100 \%$ of RPC but there were no significant differences with the other experimental groups. The feed conversion ratio of the control group was significantly decreased $(\mathrm{P} \leq 0.05)$ when compared with both $50 \%$ and $100 \%$ RPC fed groups, respectively, but no significant differences with the group of RPC $25 \%$ was detected. Regarding to the specific growth rates, the control group had marked increase $(\mathrm{P} \leq 0.05)$ specific growth rate than the both of the experimental groups of $25 \%$, and $50 \%$ RPC but no significant changes were marked with the group of RPC $100 \%$. On the other hand, protein efficiency ratios and protein efficiencies were decreased with substitution of the fish meal by RPC $25 \%, 50 \%$, and $100 \%$ than control group. The relative survival percentage was not significant between all experimental groups. The survival rate was $96.67 \%$ in $\mathrm{G} 1,95 \%$ in $\mathrm{G} 2,93.33 \%$ in $\mathrm{G} 3$ while $93.33 \%$ in $\mathrm{G} 4$. In the same line, RPC could be used without adverse effect on the growth performance reductions, within the inclusion rate of up to $20 \%$ in the rainbow trout diets (Palmegiano et al., 2006). At the same time, these results were agreed with the finding of Sanchez-Lozano et al. (2009) who discovered that there were no differences in the growth performance parameters of growing the gilthead seabream when fish meal substituted with RPC. Our results were confirmed by published data which concluded that up to 50\% FM could be replaced RPC as an alternative protein raw material in the commercial shrimp diets without any effect on the growth (Oujifard et al., 2012). More interestingly, the RPC had potentials as sustainable feed raw materials for uses in the European sea bass juvenile's diets. Dietary substitution at levels up to $25 \%$ replacement of fish meal (14\%) could be used without effects on the growth traits (Guroy et al., 2013). In addition, it had been concluded that RPC with microcapsule lysine supplementation could be replaced by a dietary $18 \%$ FM without growth changes in the Chinese soft-shelled turtle (Sun et al., 2018). 
Table 2. Effect of the replacement fish meal with rice protein concentrates in the diet of Nile tilapia (O. niloticus) on overall performance during 0 - 12 week (means $\pm \mathrm{SE}$ ).

\begin{tabular}{|c|c|c|c|c|}
\hline \multirow{3}{*}{ Parameters } & \multicolumn{4}{|c|}{ Experimental groups } \\
\hline & \multirow{2}{*}{ Control } & \multicolumn{3}{|c|}{ Rice protein concentrates (RPC) } \\
\hline & & $25 \%$ & $50 \%$ & $100 \%$ \\
\hline Initial body weight, $\mathrm{g}$ & $40.33 \pm 0.22$ & $40.97 \pm 0.26$ & $41.05 \pm 0.15$ & $40.53 \pm 0.27$ \\
\hline Final body weight, $\mathrm{g}$ & $74.69 \pm 0.16$ & $74.17 \pm 0.09$ & $74.17 \pm 0.18$ & $74.02 \pm 0.08$ \\
\hline Total gain, $\mathrm{g}$ & $34.35 \pm 0.36^{a}$ & $33.20 \pm 0.32^{a b}$ & $33.12 \pm 0.05^{b}$ & $33.49 \pm 0.35^{a}$ \\
\hline Gain, \% & $85.19 \pm 1.35^{a}$ & $81.06 \pm 1.28$ ab & $80.68 \pm 0.28^{b}$ & $82.64 \pm 1.44^{a}$ \\
\hline Total feed intake, $g$ & $69.78 \pm 0.84^{\mathrm{b}}$ & $71.51 \pm 1.28^{\mathrm{b}}$ & $73.37 \pm 0.32^{\mathrm{D}}$ & $74.12 \pm 1.02^{a}$ \\
\hline Feed conversion ratio & $2.03 \pm 0.03^{b}$ & $2.15 \pm 0.02^{\mathrm{ab}}$ & $2.22 \pm 0.01^{a}$ & $2.15 \pm 0.01^{\mathrm{a}}$ \\
\hline Specific growth rate & $0.68 \pm 0.01^{\mathrm{a}}$ & $0.66 \pm 0.01^{b}$ & $0.66 \pm 0.002^{D}$ & $0.67 \pm 0.01$ ab \\
\hline Protein efficiency ratio & $3.81 \pm 0.06{ }^{a}$ & $3.54 \pm 0.01^{\mathrm{D}}$ & $3.44 \pm 0.02^{\mathrm{D}}$ & $3.48 \pm 0.02^{\mathrm{D}}$ \\
\hline $\begin{array}{l}\text { Protein } \\
\text { efficiency }\end{array}$ & $27.30 \pm 0.33^{\mathrm{a}}$ & $25.72 \pm 0.30^{b}$ & $25.24 \pm 0.07^{b}$ & $24.70 \pm 0.19^{b}$ \\
\hline Relative survival, \% & $96.67 \pm 1.67^{\mathrm{a}}$ & $95.00 \pm 2.89^{D}$ & $93.33 \pm 1.67^{c}$ & $93.33 \pm 1.67^{c}$ \\
\hline
\end{tabular}

Chemical, amino acids analysis of whole-body composition: -

Effect of the replacement fish meal with RPC on Nile tilapia $(O$. niloticus) body composition at the end of experiment is shown in Table (3). The results showed that replacement of the $50 \%$ and $100 \%$ of fish meal with RPC recorded significant $(\mathrm{P} \leq 0.05)$ lower protein content than the control group, while group fed $25 \%$ RPC as replacement for fish meal not significantly differ than control group. On the other hand, fish meal replacement with $50 \%$ and $100 \%$ RPC recorded a significant $(\mathrm{P} \leq 0.05)$ higher fat content than control group while the group with $25 \%$ fish meal replacement with RPC not significant differ than the control group. While the all-experimental group which fed RPC-based diet recorded a significant $(\mathrm{P} \leq 0.05)$ lower Ash, calcium, and phosphorous contents than the control group. Meanwhile, the results showed that there was no significant $(\mathrm{P} \leq 0.05)$ difference in some of the amino acids like arginine, histidine, isoleucine, and valine among all experimental groups and the control group. While the all-experimental group which fed RPCbased diet showed a significant $(\mathrm{P} \leq 0.05)$ lower cysteine, lysine, methionine, serine, and threonine than the control group. In convenience with our results (Oujifard et al., 2012) reported that replacement fish meal by RPC by 25, 50, 75 and $100 \%$ not affect shrimp tail-muscle chemical composition (moisture, protein, lipid, and ash), while the dispensable and indispensable amino acids of the tail muscle of shrimp fed with 25,50 , and $75 \%$ RPC were significantly higher than the FM (0\%) and 100\% RPC diets. Moreover (Cai et al., 2018) reported that RPC supplemented with micro-lysine or crystalline lysine could replace fish meal with higher muscle fiber frequency in the 20 to $50 \mu \mathrm{m}$ class but lower $50 \mu \mathrm{m}$ class and higher cooking loss than that of the other groups. 
Furthermore, no significant difference was found in whole-body proximate compositions of blunt snout bream.

Table 3. Effect of the replacement fish meal with rice protein concentrates in the diet of Nile tilapia (O. niloticus) on body composition at the end of experiment (means $\pm \mathrm{SE}$ ).

\begin{tabular}{|c|c|c|c|c|}
\hline \multirow{3}{*}{ Parameters } & \multicolumn{4}{|c|}{ Experimental groups } \\
\hline & \multirow{2}{*}{ Control } & \multicolumn{3}{|c|}{ Rice protein concentrates (RPC) } \\
\hline & & $25 \%$ & $\mathbf{5 0 \%}$ & $100 \%$ \\
\hline DM, \% & $23.12 \pm 0.07$ & $23.00 \pm 0.14$ & $23.21 \pm 0.11$ & $23.18 \pm 0.05$ \\
\hline $\mathrm{CP}, \%$ & $61.68 \pm 0.17^{\mathrm{a}}$ & $60.99 \pm 0.14^{\mathrm{ab}}$ & $61.37 \pm 0.21^{\mathrm{a}}$ & $60.85 \pm 0.23^{b}$ \\
\hline EE, \% & $6.17 \pm 0.04^{b}$ & $6.20 \pm 0.05^{b}$ & $6.28 \pm 0.06^{a b}$ & $6.49 \pm 0.12^{a}$ \\
\hline Ash, \% & $28.40 \pm 0.22^{a}$ & $26.90 \pm 0.21^{b}$ & $26.55 \pm 0.09^{b}$ & $24.46 \pm 0.17^{c}$ \\
\hline Calcium, \% & $7.12 \pm 0.17^{\mathrm{a}}$ & $6.16 \pm 0.04^{b}$ & $6.14 \pm 0.02^{b}$ & $5.83 \pm 0.02^{c}$ \\
\hline Phosphorus, \% & $4.07 \pm 0.02^{a}$ & $3.99 \pm 0.06^{\mathrm{a}}$ & $3.40 \pm 0.13^{b}$ & $3.11 \pm 0.04^{\mathrm{c}}$ \\
\hline \multicolumn{5}{|c|}{ Amino acids percent of crude protein } \\
\hline Arginine, \% & $3.46 \pm 0.12$ & $3.41 \pm 0.03$ & $3.45 \pm 0.10$ & $3.43 \pm 0.07$ \\
\hline Cystine, \% & $0.48 \pm 0.01^{\mathrm{a}}$ & $0.44 \pm 0.02^{\mathrm{ab}}$ & $0.45 \pm 0.02^{\mathrm{ab}}$ & $0.42 \pm 0.01^{b}$ \\
\hline Histidine, \% & $0.98 \pm 0.01$ & $0.98 \pm 0.01$ & $0.98 \pm 0.02$ & $0.95 \pm 0.01$ \\
\hline Isoleucine, \% & $2.07 \pm 0.05$ & $2.11 \pm 0.09$ & $2.02 \pm 0.01$ & $2.02 \pm 0.04$ \\
\hline Lysine, \% & $3.87 \pm 0.03^{a}$ & $3.45 \pm 0.03^{b}$ & $3.44 \pm 0.02^{b}$ & $3.42 \pm 0.01^{b}$ \\
\hline Methionine, \% & $1.69 \pm 0.02^{a}$ & $1.59 \pm 0.03^{b}$ & $1.56 \pm 0.02^{b}$ & $1.53 \pm 0.05^{b}$ \\
\hline Serine, \% & $2.36 \pm 0.01^{\mathrm{a}}$ & $2.28 \pm 0.02^{b}$ & $2.25 \pm 0.003^{b}$ & $2.25 \pm 0.01^{b}$ \\
\hline Threonine, \% & $2.51 \pm 0.01^{\mathrm{a}}$ & $2.44 \pm 0.01^{\mathrm{ab}}$ & $2.42 \pm 0.01^{b}$ & $2.38 \pm 0.04^{b}$ \\
\hline Valine, \% & $2.46 \pm 0.02$ & $2.68 \pm 0.32$ & $2.68 \pm 0.34$ & $2.33 \pm 0.01$ \\
\hline
\end{tabular}

a, $b, c$ Means with different superscripts in the same column are significantly different $(p<.05)$.

\section{Intestinal histology:}

Effect of the replacement fish meal with RPC on Nile tilapia $(O$. niloticus) intestinal histology at the end of experiment is shown in Table (4) and figure (1). The intestinal histology revealed that villus height, crypt depth and muscle layer thickness were increased respectively with increasing the percent of RPC in the rations. This result was in agreement with finding of (Shi et al., 2019) as reported that replacing fish meal with plant protein source had improved intestinal histology of rice field eel.

Table 4. Effect of the replacement fish meal with rice protein concentrates on tilapia nilotica intestinal histomorphology (means \pm SE).

\begin{tabular}{|c|c|c|c|c|}
\hline \multirow[b]{2}{*}{ Parameters } & \multicolumn{4}{|c|}{ Experimental groups } \\
\hline & Control & $\begin{array}{c}\text { Rice protein } \\
\text { concentrate } \\
25 \%\end{array}$ & $\begin{array}{c}\text { Rice protein } \\
\text { concentrate } \\
50 \%\end{array}$ & $\begin{array}{c}\text { Rice protein } \\
\text { concentrate } \\
100 \%\end{array}$ \\
\hline Villi height ( $\mu \mathrm{m})$ & $222.35 \pm 0.86^{d}$ & $273.50 \pm 1.02^{c}$ & $335.75 \pm 1.45^{b}$ & $452.60 \pm 1.29^{a}$ \\
\hline Crypt depth $(\mu \mathrm{m})$ & $88.35 \pm 1.02^{d}$ & $98.10 \pm 0.98^{c}$ & $101.66 \pm 1.02^{b}$ & $131.70 \pm 1.04^{\mathrm{a}}$ \\
\hline $\begin{array}{l}\text { Muscle thickness } \\
(\mu \mathrm{m})\end{array}$ & $36.94 \pm 0.42^{b}$ & $44.60 \pm 0.68^{\mathrm{a}}$ & $44.60 \pm 0.81^{a}$ & $48.46 \pm 0.81^{a}$ \\
\hline
\end{tabular}

$\frac{(\mu \mathrm{m})}{\mathrm{a}, \mathrm{b}, \mathrm{c}, \mathrm{d}}$ Means with different superscripts in the same column are significantly different $(p<.05)$. 


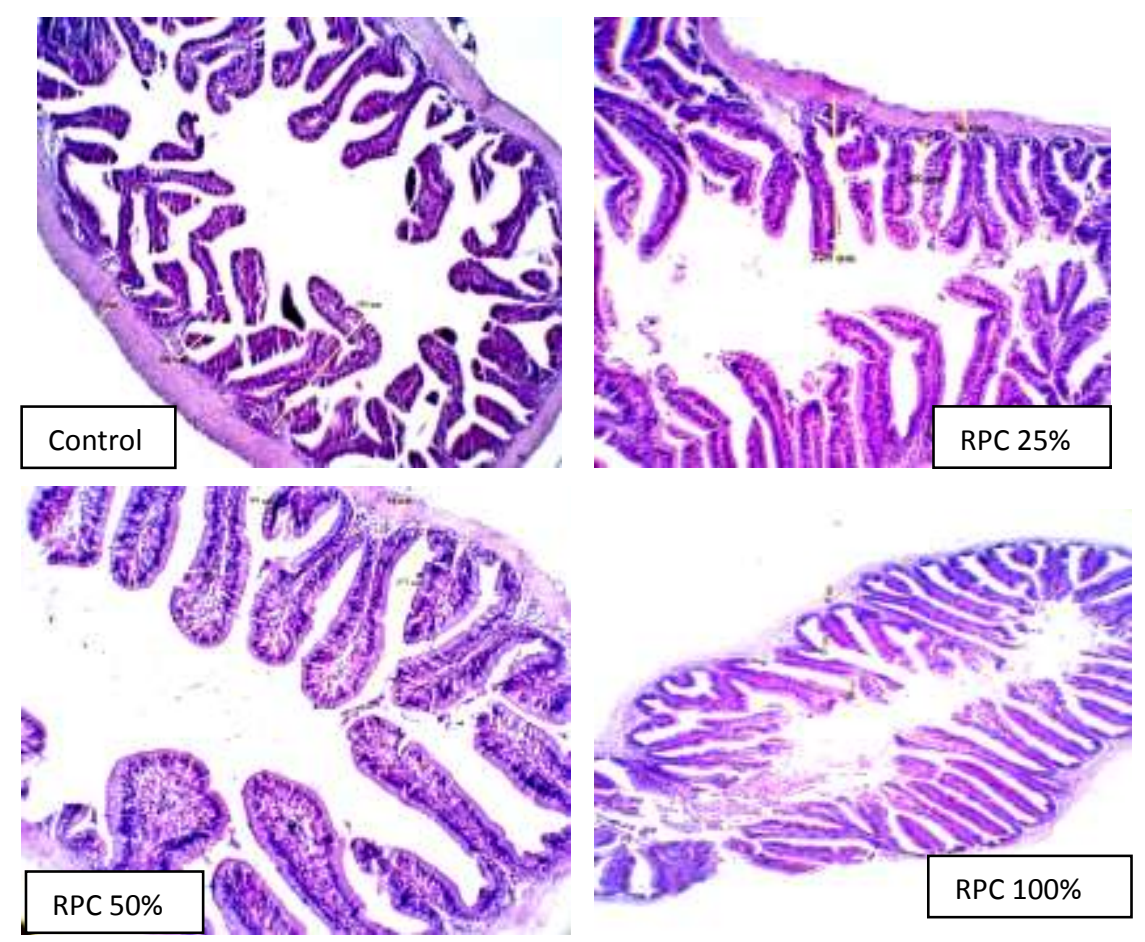

Figure 1: Effect of the replacement fish meal with rice protein CONCLUSION concentrates on tilapia nilotica intestinal histomorphology

RPC could replace fish meal in Nile tilapia feed till $100 \%$ without adverse effect on fish performance while lowered $\mathrm{cp}$, calcium, phosphorus and higher fat content of muscles as well as improved intestinal histomorphology.

\section{ACKNOWLEDGEMENTS}

This work was supported by the Faculty of Veterinary Medicine, Zagazig University, Egypt.

\section{CONFLICT OF INTEREST}

The authors declared that there are no conflicts of interest

\section{AUTHORS CONTRIBUTION}

All authors contributed equally to this work

\section{REFERENCES}

Abasubong, K.P. ; W.B. Liu ; Y.J.J. Adjoumani ; S.L. Xia ; C. Xu and X.F. Li (2019). Xylooligosaccharides benefits the growth, digestive functions and TOR signaling in Megalobrama amblycephala fed diets 
with fish meal replaced by rice protein concentrate. Aquaculture., 500: 417-428.

AOAC (2012). Official methods of analysis of AOAC International, Association of Official Analytical Chemists.

Bayse, D.D. ; E.W. Gunter ; J.W. Neese and W.E. Turner (1981) Laboratory procedures used by the Clinical Chemistry Division, Centers for Disease Control, for the Second Health and Nutrition Examination Survey (HANES II).

Cai, W.C. ; G.Z. Jiang ; X.F. Li ; C.X. Sun ; H.F. Mi ; S.Q. Liu and W.B. Liu (2018). Effects of complete fish meal replacement by rice protein concentrate with or without lysine supplement on growth performance, muscle development and flesh quality of blunt snout bream (Megalobrama amblycephala). Aquaculture Nutrition, 24(1): 481-491.

Castell, J.D. and K. Tiews (1980). Report of the EIFAC, IUNS and ICES Working Group on Standardization of Methodology in Fish Nutrition Research, Hamburg, Federal Republic of Germany, 21-23 March 1979. Documents Techniques de la CECPI (FAO).

Dapra, F. ; F. Gai ; M.T. Costanzo ; G. Maricchiolo ; V. Micale ; B. Sicuro and G.B. Palmegiano (2009). Rice protein concentrate meal as a potential dietary ingredient in practical diets for blackspot seabream Pagellus bogaraveo: a histological and enzymatic investigation. J. Fish Boil. 74(4): 773-789.

Dipietro, E.S. ; M.M. Bashor ; P.E. Stroud ; B.J. Smarr ; B.J. Burgess ; W.E. Turner and J.W. Neese (1988). Comparison of an inductively coupled plasma-atomic emission spectrometry method for the determination of calcium, magnesium, sodium, potassium, copper and zinc with atomic absorption spectroscopy and flame photometry methods. Science of the total environment, 74: 249-262.

Feldsine, P. ; C. Abeyta and W.H. Andrews (2002). AOAC International methods committee guidelines for validation of qualitative and quantitative food microbiological official methods of analysis. J. A.O.A.C. Internat., 85(5): 1187-1200

Garde-Cerdán, T. ; R. López ; J. Portu ; L. González-Arenzana ; I. LópezAlfaro and P. Santamaría (2014). Study of the effects of proline, phenylalanine, and urea foliar application to Tempranillo vineyards on grape amino acid content. Comparison with commercial nitrogen fertilisers. Food chemistry, 163: 136-141.

Gatlin, D.M. ; F.T. Barrows ; P. Brown ; K. Dabrowski ; T.G. Gaylord ; R.W. Hardy and K. Overturf (2007). Expanding the utilization of sustainable plant products in aquafeeds: a review. Aquaculture research, 38(6): 551-579. 
Guroy, D. ; İ. Şahin ; B. Guroy ; D.L. Merrifield ; M. Bulut and A.A. Tekinay (2013). Replacement of fish meal with rice protein concentrate in practical diets for European sea bass Dicentrarchus labrax reared at winter temperatures. Aquacult. Res., 44(3): 462-471.

Jauncey, K. and B. Ross (1982). A guide to tilapia feeds and feeding. University of Stirling. Institute for Aquaculture, Stirling, UK.

Katya, K. ; Y.H. Yun ; G. Park ; J.Y. Lee ; G. Yoo and S.C. Bai (2014). Evaluation of the efficacy of fermented by-product of mushroom, Pleurotus ostreatus, as a fish meal replacer in juvenile Amur catfish, Silurus asotus: effects on growth, serological characteristics and immune responses. Asian-Australasian journal of animal sciences, 27(10): 1478 .

Nathanailides, C. ; D. Klaoudatos ; C. Perdikaris ; S. Klaoudatos ; M. Kolygas and F. Athanassopoulou (2019). Metabolic differentiation of diploid and triploid European sea bass juveniles. Internat. Aquatic Res. 11(2): 199-206.

National Research Council (1993). Nutrient requirements of fish. National Academies Press.

Olsen, R.L. and M.R. Hasan (2012). A limited supply of fish meal: Impact on future increases in global aquaculture production. Trends in Food Science \& Technology, 27(2): 120-128.

Oujifard, A. ; J. Seyfabadi ; A.A. Kenari and M. Rezaei (2012). Fish meal replacement with rice protein concentrate in a practical diet for the Pacific white shrimp, Litopenaeus vannamei Boone, 1931. Aquaculture International, 20(1): 117-129.

Palmegiano, G.B. ; F. Daprà ; G. Forneris ; F. Gai ; L. Gasco ; K. Guo and I. Zoccarato (2006). Rice protein concentrate meal as a potential ingredient in practical diets for rainbow trout (Oncorhynchus mykiss). Aquaculture, 258(1-4): 357-367.

Roberts, R. J. (2012). Fish pathology. John Wiley \& Sons.

Sanchez-Lozano, N.B. ; S. Martinez-Llorens ; A. Tomas-Vidal and M.J.Cerda (2009). Effect of high-level fish meal replacement by pea and rice concentrate protein on growth, nutrient utilization and fillet quality in gilthead seabream (Sparusaurata, L.). Aquaculture., 298(12):83-89.

Santiago, C.B. ; M. Banes-Aldaba and M.A. Laron (1982). Dietary crude protein requirement of Tilapia nilotica fry Kalikasan, philipp. J. Biol., 11(2-3): 255-265.

Shi, Y. ; L. Zhong ; X. Ma ; Y. Liu ; T. Tang and Y. Hu (2019). Effect of replacing fish meal with stickwater hydrolysate on the growth, serum biochemical indexes, immune indexes, intestinal histology and microbiota of rice field eel (monopterus albus). Aquaculture Reports, 15: 100223. 
Siddiqui, A.Q. ; M.S. Howlader and A.A. Adam (1988). Effects of dietary protein levels on growth, feed conversion and protein utilization in fry and young Nile tilapia, Oreochromis niloticus. Aquaculture., 70(1-2): 63-73.

Stuart, J.S. and S.S. Hung (1989). Growth of juvenile white sturgeon (Acipenser transmontanus) fed different proteins. Aquaculture., 76(34): 303-316.

Sun, C.X. ; D.D. Zhang ; W.B. Liu ; W.C. Cai ; Y. Qian ; K.Z. Wang and W.N. Xu (2018). Growth performance, digestion and metabolism to fish meal replacement by rice protein concentrate in Chinese softshelled turtle Pelodiscussinensis. Aquaculture., 492: 321-326.

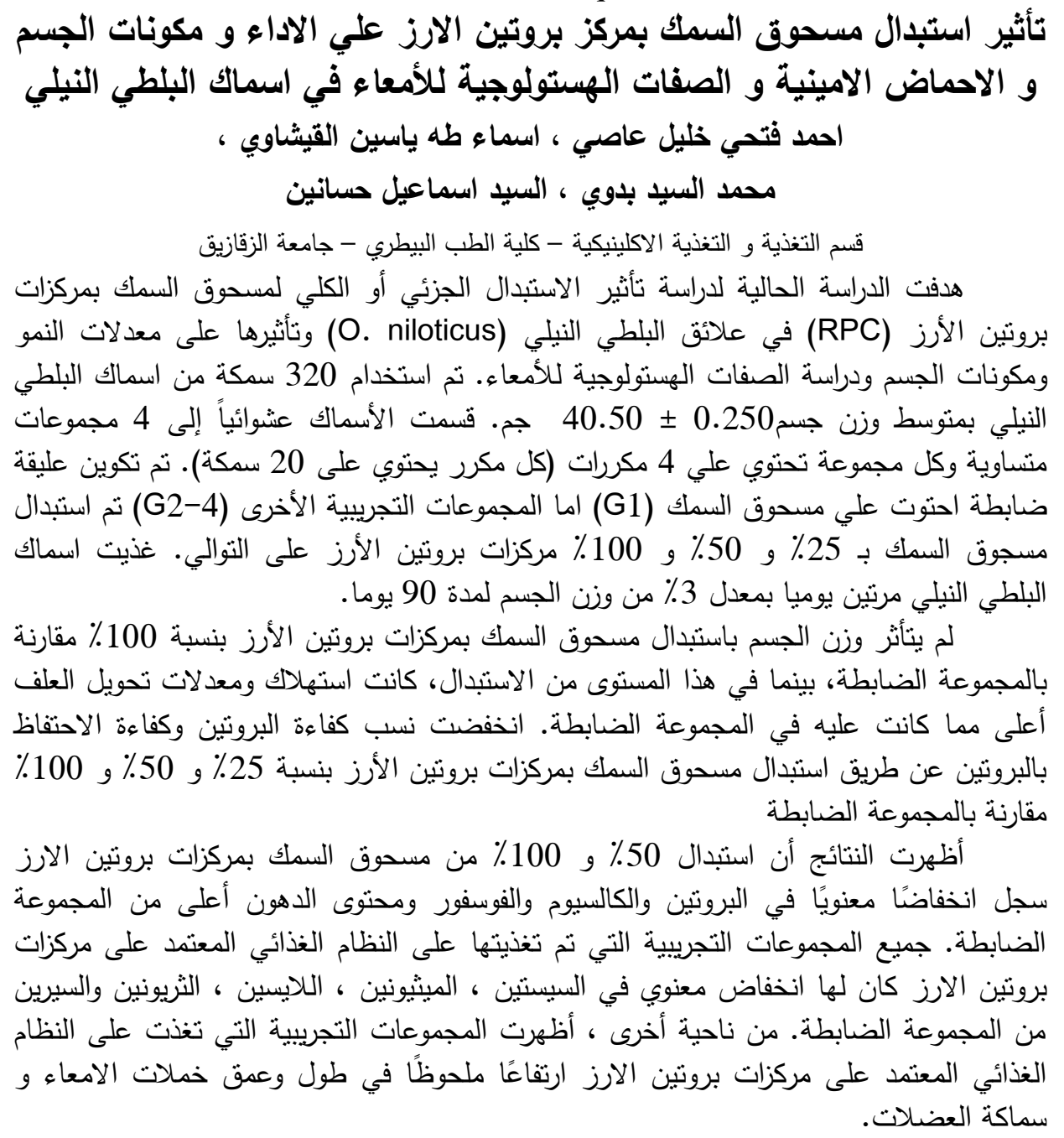

